\title{
Communicating Science through a Novel Type of Journal
}

\author{
Michelle T. Juarez, ${ }^{*}$ Chloe M. Kenet, and Chiandredi N. Johnson \\ Sophie Davis Program in Biomedical Education, City University of New York School of Medicine, \\ City College of New York, New York, NY 10031
}

To the Editor:

We would like to bring to the attention of the CBE-Life Sciences Education (LSE) community an online journal, Frontiers for Young Minds (http://kids.frontiersin.org), which is designed to promote scientific communication with the general public, especially young people. Launched in 2013 by a group from University of California at Berkeley led by Dr. Robert T. Knight, Frontiers for Young Minds serves as an openaccess resource that not only creates science literature for a younger audience but also brings kids into the review process. Specifically, scientists write kid-friendly versions of their articles, which are then reviewed by young people in the target age range for the pieces (ages 8-15). Authors "translate" the main ideas in the articles through the use of keywords as well as a glossary section to define any scientific nomenclature. Frontiers for Young Minds uses two article formats: 1) new discovery—to introduce a recent development in science by highlighting a previously published and peer-reviewed article; and 2) core concept - to provide a kid-friendly explanation of a fundamental scientific idea. A science mentor other than the authors guides the young reviewer through the review process. In an online discussion forum curated by the Frontiers for Young Minds editors, the authors and mentors discuss the comments from the young reviewers and work together to identify components of the articles that spark the curiosity of the kids and concepts that need further clarification. Frontiers for Young Minds publishes articles in a wide range of disciplines, including astronomy and space science, biodiversity, health, neuroscience, and earth and its resources. All articles include online profile links to all of the authors and the young reviewers. The submission process is free for the authors and follows an easy-to-navigate online platform to communicate with the editors, reviewers, and production staff.

We published a new discovery format article in Frontiers for Young Minds as part of a creative writing project in Juarez's research lab. We wrote a piece on a PLoS Genetics article (Juarez et al., 2011) on transcriptional responses to epidermal wounding in Drosophila (www.jove.com/video/50750/microinjection-wound-assay-vivo-localization -epidermal-wound-response). We also integrated content from an article published in Journal of Visualized Experiments (Juarez et al., 2013) to provide a visual aid for understanding how we conducted our wound assays. We created artistic interpretations of results and figures to illustrate key points of the research. For example, we created an "ouch scale" to quantify the results and help the young readers interpret them. We also created an image to highlight a curious child with a magnifying glass, a fruit fly, and DNA (Figure 1), because we hoped it would help young readers see themselves contributing to the scientific endeavor. The feedback from our young reviewer helped us to clarify the overall message of the article, especially as it related to fundamental concepts of DNA and genetics. The young reviewer was intrigued by the idea of doing experiments with Drosophila and using the results to impact human health. The final product of this writing exercise is a Frontiers for Young Minds article (http://kids .frontiersin.org/article/10.3389/frym.2016.00027).

We invite LSE readers to share their biological research through Frontiers for Young Minds and to encourage their colleagues, including undergraduates, graduate students, postdoctoral associates, and other scientists, to do so. We found the process
CBE Life Sci Educ June 1, 2017 16:le2 DOI:10.1187/cbe.16-12-0345

*Address correspondence to: Michelle T. Juarez (mjuarez@med.cuny.edu).

(C) 2017 M. T. Juarez et al. CBE-Life Sciences Education (C) 2017 The American Society for Cell Biology. This article is distributed by The American Society for Cell Biology under license from the author(s). It is available to the public under an Attribution-Noncommercial-Share Alike 3.0 Unported Creative Commons License (http://creativecommons.org/licenses/ by-nc-sa/3.0).

"ASCB®" and "The American Society for Cell Biology ${ }^{\circledR}$ " are registered trademarks of The American Society for Cell Biology. 


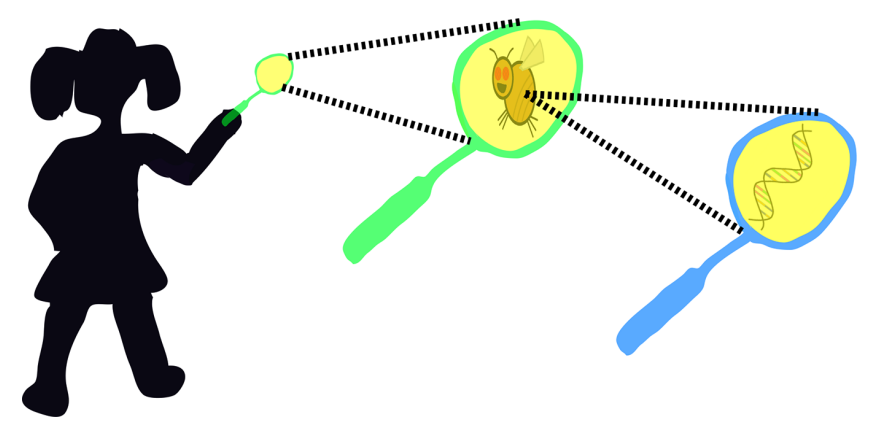

FIGURE 1. Lessons from the fruit fly. A creative drawing project to summarize the use of fruit flies as a model to study genetics. $A$ young child has a magnifying glass to look at the fruit fly. A second magnifying glass looks inside the fruit fly to visualize the DNA.

of editing and creating science-related artwork quite useful for developing our own science communication skills, and it provided an entry point for a broader group of students to actively engage in science. We think Frontiers for Young Minds presents a unique opportunity to study how writing for public audiences influences scientists' model-based reasoning (Quillin and Thomas, 2015) and communication skills as well as young readers' science literacy. We also think the journal provides a unique environment for exploring the integration of science and art as a tool for improving student learning and inclusion (Campbell et al., 2014).

\section{ACKNOWLEDGMENTS}

This work was supported by a grant from the National Institutes of Health (NIH) National Institute of Allergy and Infectious Diseases (R03AI117671) to M.T.J. and institutional support to the City College of New York from the NIH National Cancer Institute (U54CA137788/U54CA132378) and the NIH National Institute on Minority Health and Health Disparities (8G12MD7603).

\section{REFERENCES}

Campbell AG, Skvirsky R, Wortis H, Thomas S, Kawachi I, Hohmann C (2014). NEST 2014: views from the trainees-talking about what matters in ef forts to diversify the STEM workforce. CBE Life Sci Educ 13, 587-592.

Juarez MT, Patterson RA, Li W, McGinnis W (2013). Microinjection wound assay and in vivo localization of epidermal wound response reporters in Drosophila embryos. J Vis Exp 81, e50750.

Juarez MT, Patterson RA, Sandoval-Guillen E, McGinnis W (2011). Duox, Flotillin-2, and Src42A are required to activate or delimit the spread of the transcriptional response to epidermal wounds in Drosophila. PLoS Genet 7, e1002424

Quillin K, Thomas S (2015). Drawing to learn: a framework for using drawings to promote model-based reasoning in biology. CBE Life Sci Educ 14, es2. 